\title{
New contributions to the phylogenetic position of the sauropod Galvesaurus herreroi from the late Kimmeridgian-early Tithonian (Jurassic) of Teruel (Spain)
}

\author{
M. Pérez-Pueyo ${ }^{(1)}$, M. Moreno-Azanza ${ }^{(1,2,3)}$, J. L. Barco ${ }^{(1,4)}$ and J. I. Canudo ${ }^{(1,5)}$ \\ (1) Aragosaurus: Recursos geológicos y paleoambientes, IUCA, Facultad de Ciencias, \\ Universidad de Zaragoza, Pedro Cerbuna, 12; 50009 Zaragoza, Spain. \\ manuppueyo@gmail.com \\ (2) Geobiotec. Departamento de Ciências da Terra., DCT. Faculdade de Ciências e Tecnologia. \\ Universidade Nova de Lisboa, Monte da Caparica, 2829-516, Caparica, Portugal. \\ (3) Museu da Lourinhã. Rua Louis de Moura 95, 2530-154, Lourinhã, Portugal. \\ (4) Paleoymás. Polígono INBISA - Empresarium, c/ Retama, 17 Nave 24C, 50720 Cartuja Baja, Zaragoza, Spain. \\ (5) Museo de Ciencias Naturales de la Universidad de Zaragoza, \\ Edificio Paraninfo, Pza. Basilio Paraíso, 4; 50005 Zaragoza, Spain.
}

\begin{abstract}
Galvesaurus herreroi is a sauropod from the Villar del Arzobispo Formation (late Kimmeridgian-early Tithonian), from the municipality of Galve (Teruel). Its phylogenetic relations have been long debated, so we carried out a phylogenetic analysis, using a new data matrix recently published by Carballido et al. (2017). The characters of Galvesaurus were coded on the basis of the redescription of the published remains and the description of two unpublished fossils: a right coracoid and a fragment of the right pubis. The results of the analysis suggest the inclusion of Galvesaurus in the clade Titanosauriformes, as a sister taxon to Lusotitan, these two taxa form part of the Brachiosauridae clade. Likewise, a stratigraphic study was undertaken, placing the Galvesaurus site in the lower part of the Villar del Arzobispo Formation, thus assigning the sauropod a late Kimmeridgian-early Tithonian age.
\end{abstract}

Keywords: Brachiosauridae, cladistics, Iberian Range, Kimmeridgian, sauropods.

\section{Nuevas aportaciones a la posición filogenética del saurópodo Galvesaurus herreroi del Kimmeridgiense superior-Titoniense inferior (Jurásico) de Teruel (España)}

\section{RESUMEN}

Galvesaurus herreroi es un saurópodo recuperado en la Formación Villar del Arzobispo (Kimmeridgiense superior-Titoniense inferior), del término municipal de Galve (Teruel). Sus relaciones filogenéticas han sido largamente discutidas, para dar solución a este problema se ha llevado a cabo un análisis filogenético, con nuevos datos y usando una moderna propuesta filogenética (Carballido et al., 2017). Los caracteres de Galvesaurus se han codificado basándose en la redescripción de los restos publicados y en la descripción de dos fósiles inéditos: el coracoides derecho y un fragmento del pubis derecho. Los resultados del análisis inducen a proponer la inclusión de Galvesaurus en el clado Titanosauriformes, como taxón hermano de Lusotitan, y siendo incluidos ambos dentro de Brachiosauridae. Así mismo, se ha realizado un estudio estratigráfico que sitúa el yacimiento de Galvesaurus en la parte baja de la Formación Villar del Arzobispo, asignándole al saurópodo una edad Kimmeridgiense superior-Titoniense inferior.

Palabras clave: Brachiosauridae, cladística, Cordillera Ibérica, Kimmeridgiense, Sauropoda. 
M. Pérez-Pueyo, et al., 2019. New contributions to the phylogenetic position of the... Boletín Geológico y Minero, 130 (3): $375-392$

\section{Introduction and background}

The continental Jurassic-Cretaceous boundary is characterized by a faunal turnover in the vertebrate fossil record, especially among large-sized terrestrial vertebrates such as dinosaurs (Bakker, 1998; Barret et al., 2009; Tennant et al., 2017). This interval of transition led to a renewal of dinosaur faunas, resulting in the emergence of the main groups of dinosaurs that characterized the Cretaceous. However, there are still many gaps in what is known about this question, so every new discovery sheds light on the issue.

The Iberian Range is one of the places in the world where the transition between the Jurassic and the Cretaceous is exemplified by the associated vertebrate remains (Aurell et al., 2016). In this area, vast outcrops of transitional-continental formations can be found, traditionally representing the deposits of the uppermost Jurassic and the transition to the Lower Cretaceous (Aurell et al., 1994; Mas et al., 2004). These formations are rich in vertebrate fossils and dinosaur tracks, with remains of ornithopods, thyreophorans, sauropods and theropods. Amongst the discoveries, a few stand out, such as the stegosaur Dacentrurus (Cobos et al., 2010), theropods (Canudo et al., 2006), and the sauropods Losillasaurus, Turiasaurus and Galvesaurus (Casanovas et al., 2001; Royo-Torres et al., 2006; Barco et al., 2005). These findings are complemented by a rich record of dinosaur tracks, including tracks belonging to ornithopods (Castanera et al., 2013), thyreophorans (Cobos et al., 2010) sauropods (Castanera et al., 2011) and theropods (Cobos et al., 2014).

The sauropod Galvesaurus in itself raises a number of questions. Beyond its problematic definition with different names (for further references see Barco et al., 2012), this sauropod has had an unstable phylogenetic position within the clade Sauropoda. Galvesaurus has been located both inside and outside the clade Neosauropoda in different research. Barco (2005, 2009, 2010), Carballido et al. (2011) Barco and Canudo (2012) classify Galvesaurus as a macronarian neosauropod, whereas SánchezHernández (2005) included it in Cetiosauridae (as a non-neosauropod eusauropod). Furthermore, RoyoTorres et al. (2006) classify it as Turiasauria, meanwhile D'Emic (2012) considers Galvesaurus as a putative titanosauriform, with possible brachiosaurid affinities. Finally, Mocho et al., (2017) also recovered Galvesaurus as putative brachiosaurid, and consider it to be particularly difficult to distinguish Galvesaurus from Lusotitan, and they do not exclude the possibility of Galvesaurus herreroi being a junior synonymous of Lusotitan atalaiensis. The phylogenetic position of Galvesaurus has shown a high degree of uncertainty, since the skeleton was not complete and the area of the cladogram where Galvesaurus is situated has been characterized by low stability due to the scarcity of basal neosauropods. During the last decade, important advances have been made in what is known of the basal neosauropods as a result of the study of new taxa, which has allowed the resolution in this part of the cladogram to be improved (e.g. Europasaurus, Sander et al., 2006; Lourinhasaurus, Mocho et al., 2014; Padillasaurus; Carbadillo et al., 2015). We have also studied unpublished material from the type specimen of Galvesaurus, which has helped us to fill some of the gaps in the matrix of characters.

Moreover, the age of Galvesaurus has been too unstable, due to the fact that that the stratigraphic position of its type locality has never been located with enough resolution (Barco, 2009; Royo-Torres et al., 2009), and the age of Villar del Arzobispo Fm. has been widely discussed (Aurell et al., 2016; CamposSoto et al., 2017; Val et al., 2018). Therefore, a detailed stratigraphic study was needed in order to fix the stratigraphic position of Galvesaurus in the most recent chronostratigraphic proposal (Val et al., 2018). For all these reasons, the main objective of this study was to carry out a new phylogenetic analysis for Galvesaurus herreroi with an updated matrix (Carballido et al., 2017), in order to clarify its phylogenetic relationships and unearth its palaeobiogeographic implications.

\section{Geographical and geological setting}

The holotype of Galvesaurus herreroi was found in the area around the village of Galve, in the central part of the province of Teruel, NE Spain (Fig. 1A). The site where the Galvesaurus fossils were discovered, "Cuesta Lonsal-1" (CL), is located around half a kilometre west of Galve (Fig. 1B). Geologically, the Cuesta Lonsal-1 site is located in the western limb of the Galve syncline, a N-S oriented fold, made up of marine, transitional and continental deposits from the Late Jurassic to Early Cretaceous (Díaz-Molina and Yébenes, 1987; Soria, 1997; Aurell et al., 2016). This syncline is part of the Galve sub-basin, and is situated in its northwest area (Fig. 2A). Along with six other sub-basins, this sub-basin makes up the Mesozoic Maestrazgo Basin (Salas et al., 2001).

The 'Cuesta Lonsal-1' site is included within the Villar del Arzobispo Fm. (Aurell et al., 2016), which, along with the overlying Aguilar del Alfambra Fm., 


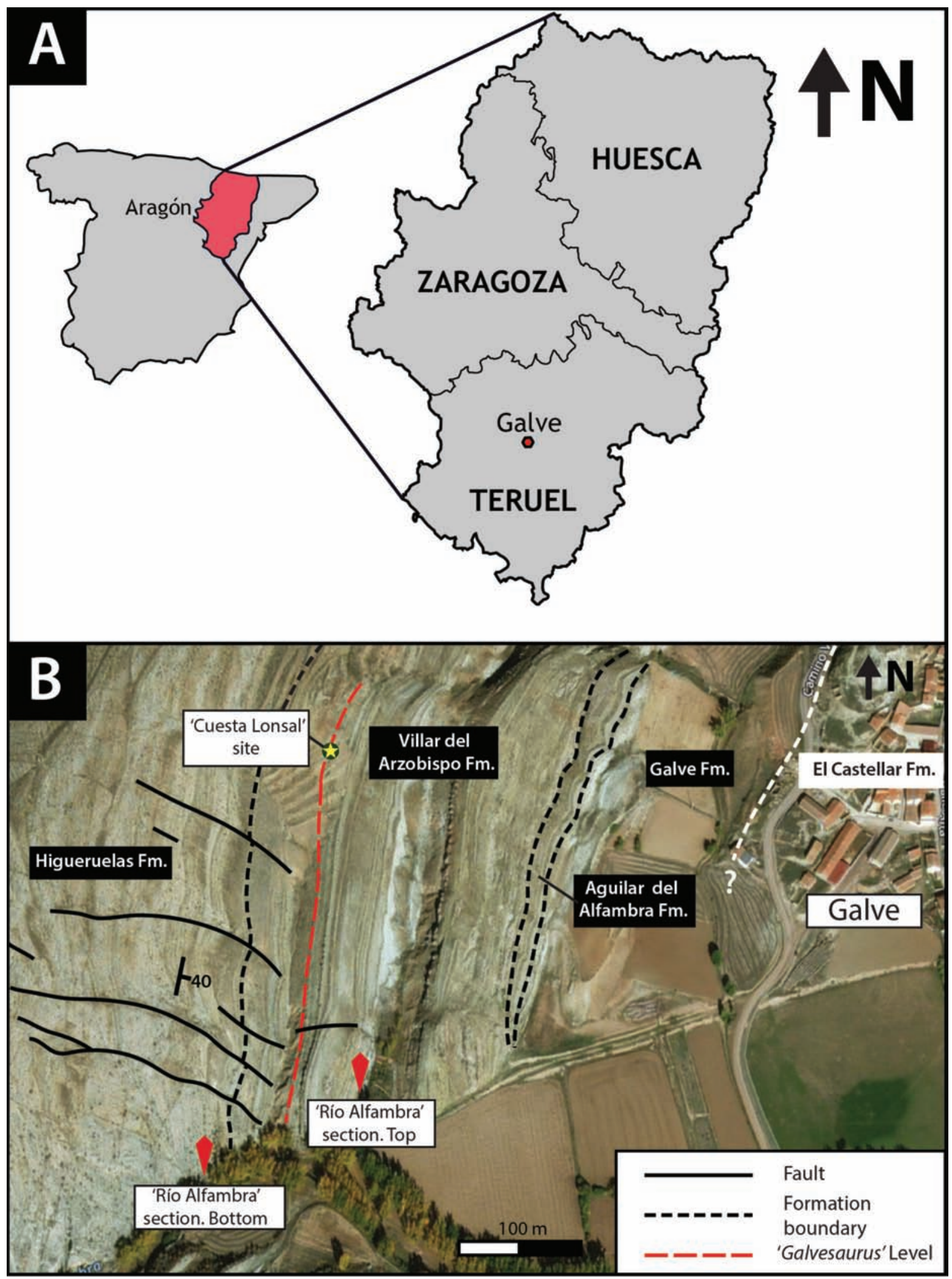

Figure 1. A) Geographic location of Galve (Teruel). B) Detailed aerial photo of the outcrops situated WSW of Galve, where the fossils were found (available in https://www.bing.com/maps).

Figura 1. Situación geográfica de Galve (Teruel). B) Foto aérea detallada de los afloramientos situados al OSO de Galve, donde fueron hallados los fósiles (disponible en https://www.bing.com/maps). 


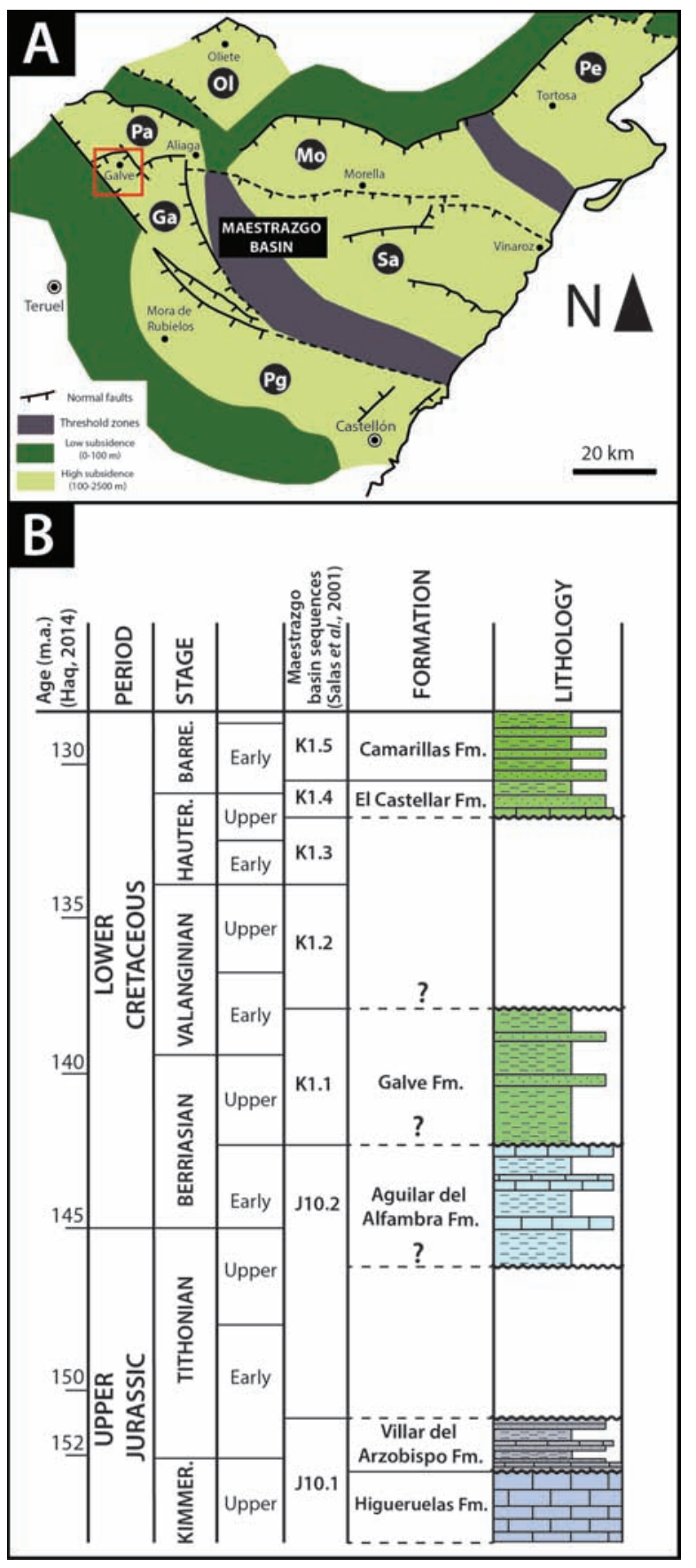

Figure 2. A) Palaeogeography of Maestrazgo sedimentary basin and its main sub-basins during the Lower Cretaceous $(\mathrm{Ga}$, Galve; Mo, Morella; OI, Oliete; Pa, Las Parras; Pe, Perelló; Pg, Peñagolosa; Sa, Salzedella). Modified from Salas et al. (2001) and Aurell et al. (2016). B) Synthetic stratigraphy of the Jurassic-Cretaceous boundary succession recorded in the depocentral areas of the Galve subbasin. Adapted from Aurell et al. (2016).

Figura 2. A) Paleogeografía de la cuenca sedimentaria del Maestrazgo y sus principales subcuencas durante el Cretácico Inferior (Ga, Galve; Mo, Morella; Ol, Oliete; Pa, Las Parras; Pe, Perelló; Pg, Peñagolosa; Sa, Salzedella). Modificado de Salas et al. (2001) y Aurell et al. (2016). B) Estratigrafía sintética de la sucesión del límite Jurásico-Cretácico registrada en los depocentros de la subcuenca de Galve. Adaptado de Aurell et al. (2016). corresponds to the Purbeck facies, which represent the Tithonian-Berriasian sequence (J10) of the basin (Salas et al., 2001) (Fig. 2B). The Villar del Arzobispo $\mathrm{Fm}$. is constituted by an alternation of carbonate, sandy and muddy levels, representing a wide set of transitional depositional environments (Díaz-Molina et al., 1984; Aurell et al., 1994). The limestone is both peloidal and grain-supported, corresponding to lagoon and carbonate tidal-flat deposits (Díaz-Molina and Yébenes, 1987; Aurell et al., 2016), whereas the terrigenous deposits represent delta and delta-plain environments with a marked fluvial influence (DíazMolina and Yébenes, 1987; Barco, 2009). In Galve, the Villar del Arzobispo Fm. is limited by two low-angle erosive unconformities as its lower and upper boundaries (Canudo et al., 2012; Aurell et al., 2016), being situated between the Jurassic marine Higueruelas Fm. and the transitional Early Cretaceous Aguilar del Alfambra Fm. (Fig. 2B).

\section{Material and methods}

\section{Institutional abbreviations}

The fossils studied in this paper are housed in the Museo Paleontológico de Galve $(\mathrm{CL}, \mathrm{CLH})$, in the Museo de Ciencias Naturales de la Universidad de Zaragoza (MPZ, see Canudo, 2018) and in the Gobierno de Aragón (GAL).

\section{Anatomical nomenclature}

For the description of the bones, we use the standardized anatomical nomenclature based on the Nomina Anatomica Avium and Nomina Anatomica Veterinaria (see Harris, 2004). The nomenclature for the vertebral laminae follows Wilson (1999), with modifications (apcdl) from Salgado et al. (2005) and Wilson et al. (2011). The nomenclature for the vertebral pneumatic structures follows Wedel (2003) and Wilson et al. (2011).

For this study, the existing Galvesaurus remains were re-examined. A broad description of these bones is to be found in various articles (Barco, 2005; Barco et al., 2005, 2006; Barco and Canudo, 2012) and especially in the doctoral thesis of Barco (2009). In this study, these descriptions were reviewed and updated, noting those aspects that were relevant for the phylogenetic analysis. In addition, some Galvesaurus bones were studied for the first time: the right coracoid (CL-CBC-908) and a distal part of the right pubis (GAL01/CL/150). 
The phylogenetic position of Galvesaurus was analysed using the data matrix of Carballido et al. (2017) with modifications from Canudo et al. (2018). The data matrix was constructed using Mesquite V. 3.31 (Maddison and Maddison, 2017). This matrix has 412 characters coded for 90 sauropod taxa. For Galvesaurus, 153 characters were coded, $37 \%$ of the total. We also recoded Lusotitan atalaiensis, taking into account the new description and recently published data (Mannion et al., 2013; Mocho et al., 2017). Information on the data matrix and the modifications in the characters of Lusotitan are included in Appendix 1.

An equally weighted parsimony analysis was carried out using TNT v.1.5 (Goloboff and Catalano, 2016), a heuristic tree search was performed, starting from 1000 replicates of Wagner trees followed by TBR branch swapping and holding 10 trees per replication. This was followed with an additional round of tree bisection and reconnection (TBR) and Branch support was assessed with Bremer decay index and a 1000 replicates of standard bootstrap analysis.

A stratigraphic section ('Río Alfambra' section, RA) was studied (Fig. 1B, Fig. 3) in order to fix the position of the Galvesaurus site and other fossil vertebrate sites within the Villar del Arzobispo Fm. Thus, the age of these sites was calibrated with the new chronostratigraphic frame proposed by Aurell et al. (2016).

\section{Results}

\section{Detailed stratigraphy}

The 'Río Alfambra'(RA) log encompasses a stratigraphic section of approximately $65 \mathrm{~m}$ (Fig. 3). This stratigraphic section encompasses the last levels of the Higueruelas $\mathrm{Fm}$. and the lower part of the Villar del Arzobispo Fm. (Fig. 1B and 3). Log bottom coordinates are UTM 30T 06783704502169 and top coordinates are 30T 06784914502218 , with WGS84 datum. The layers show a general strike and dip of $035,40 \mathrm{SE}$ (Fig. 1B).

The RA section is characterized by an alternation of carbonate and terrigenous beds. The top of the Higueruelas Fm. consists of several peloidal-bioclastic limestones, with occasional quartz grains. On at least two of these levels, dinosaur tracks have been recognized. The tracks situated in the uppermost level of the formation (Fig. 3) correspond to the site 'Ríos Bajos' studied by Pérez-Lorente and Romero-Molina (2001), who identify them as being produced by theropod dinosaurs.

The Villar del Arzobispo Fm. begins with an alter- nation of fine-grained limestone, marls and ochre mudstones, which is culminated by a bioturbated sandstone bed with cross-bedding. Above this bed, a set of peloidal-bioclastic limestone can be recognized, with several beds bearing vertebrate bones (Fig. 3). The limestone is followed by a detritic section of about $14 \mathrm{~m}$, constituted by a thick succession of reddish and greenish mudstones, with several sandstone levels intercalating. The uppermost sandstone level (Fig. 3), has a channelized base and shows trough cross-bedding, microconglomerate lags and bioturbation. At the base of this level, large sauropod tracks have been described (Castanera et al., 2010). Furthermore, the type locality (CL) of Galvesaurus, situated between the top of the sandstone level and the overlying grey mudstone, with fossils having been recovered from both levels (Barco, 2009). This level corresponds to the top of sequence S1 of the Villar del Arzobispo sensu Val et al. (2018, Fig. 3).

The succession continues with another carbonated interval of peloidal limestone and marls with occasional microconglomerate levels, and mudstone and marl beds with root bioturbations (Fig. 3). Occasionally, isolated tracks can be observed in some of the limestone levels. A short detritic interval overlies the above-mentioned carbonated levels, comprising a thick sandstone bed with cross-bedding, and a much thinner mudstone and sandstone alternation. These are overlaid by a new set of limestone, bearing several vertebrate remains, including bones and tracks. The last level of this succession of fine-grained limestone corresponds to the level of 'El Cantalar', where sauropod and theropod tracks were described by Pérez-Lorente and Herrero-Gascón (2007).

\section{Palaeontological study}

\author{
Systematic paleontology \\ DINOSAURIA Owen, 1842 \\ SAURISCHIA Seeley, 1887 \\ SAUROPODOMORPHA Huene, 1932 \\ SAUROPODA Marsh, 1878 \\ NEOSAUROPODA Bonaparte 1986 \\ TITANOSAURIFORMES Salgado et al., 1997 \\ BRACHIOSAURIDAE Riggs, 1904
}

\section{Genus Galvesaurus Barco, Canudo, Cuenca-Bescós and Ruiz-Omeñaca, 2005}

Type species: Galvesaurus herreroi Barco, Canudo, Cuenca-Bescós and Ruiz-Omeñaca, 2005

Holotype: A dorsal vertebra (CLH-16); figured in Pérez-Oñate et al., 1994: Fig. 2; Cuenca-Bescós et al., 


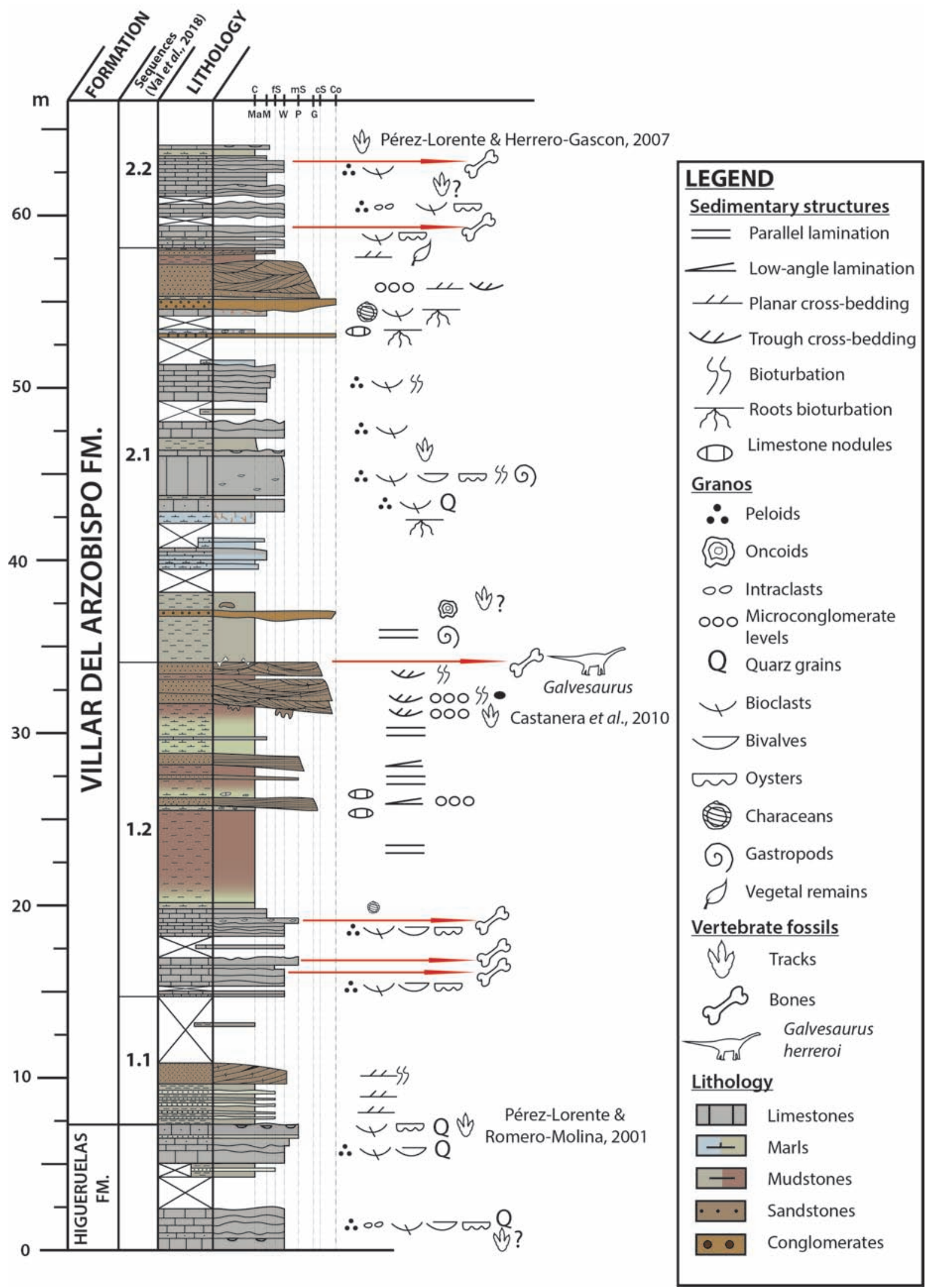

Figure 3. Stratigraphic section 'Río Alfambra' (RA), with the main fossil sites.

Figura 3. Sección estratigrafía 'Río Alfambra' (RA), con los principales yacimientos de fósiles. 
1997: Fig. 3; Barco, 2003: Figs. 34-43, 44c; 1; Barco, 2005: Fig. 3c; lams. 1, 2; Barco et al., 2005: Fig. 11; Sánchez-Hernández, 2005: Fig. 2; Barco, 2009: Fig. 4.3.1; Barco and Canudo, 2012: Fig. 2).

Paratype: 4 cervical vertebrae (CL-2; GAL00/CL/48; CL (CBC) 15-4; MPZ-2003/884); 2 cervical ribs (GAL00/CL/60; GAL00/CL/181); 3 dorsal spines (CL$\mathrm{JMH} ; \quad$ GAL00/CL/86; GAL00/CL/62); a sacrum (GAL01/CL/90); 2 dorsal ribs (CLH-5; GAL01/CL/102) and a dorsal rib fragments (; $\mathrm{CLH}-22) ; 6$ caudal vertebrae (CLH-8; CLH-15; GAL00/CL/35; CLH; CL (CBC)-31 two fused vertebrae); a haemal arch (without an acronym, fused to $\mathrm{CL}(\mathrm{CBC})-31$ ); right scapula (CLH14); both humeri (CLH-1 right, $\mathrm{CLH}-4$ left); right ischium (CLH-6); and a sternal plate (CLH-7).

Assigned material: a fragment of the right coracoid fragment (CL-CBC-908), a fragment of the right pubis (GAL01/CL/150).

\section{Description}

Galvesaurus is represented by an incomplete specimen, lacking any cranial remains and with only a few vertebrae preserved (4 cervical, 1 dorsal, 1 sacrum and 6 caudal). Barco et al. (2005) and Barco (2009) provide an extended description of the bones. Here we only describe as succinctly as possible those elements that have been reinterpreted and are relevant for the cladistics analysis.

The cervical vertebrae are generally poorly preserved, usually with the neural arch and the spine eroded, so that the description is based on CL-2, which is the best-preserved vertebra. CL-2 could be situated between the tenth and the thirteenth position (Barco, 2009) (Fig. 4A). The centrum of CL-2 is opisthocoelous, and subcircular in section. It is elongated anteroposteriorly, though not very markedly, with an elongation index aEl (after Chure et al., 2010) of 1.77 (Table 1). Ventrally, the centrum shows a groove limited to the middle part. It also presents pleurocoels in its lateral faces, drop-shaped (Fig. 4A) and divided by a thin lamina, which marks an anterior and a posterior excavation; this division is also observed in GAL00/CL/48 centrum. Internally, it shows stronglydeveloped pneumaticity, divided internally into camerae and camellae. The neural arch of the vertebra possesses a well-developed system of laminae (Fig. 4A), as shown by all the eusauropods (Wilson, 2002). These laminae include: anterior centrodiapophyseal (acdl) and posterior centrodiapophyseal (pcdl), centroprezygapophyseal (cprl), which are divided dorsally into lateral and medial cprl, intraprezygapophyseal (tprl), centropostzygapophyseal (cpol), prezygodiapophyseal (podl, postzygodiapophyseal (podl) and spinoprezygapophyseal (sprl). Acdl and pcdl are the only laminae that connect the neural arch with the centrum, the rest of the laminae being connected directly with them instead of the centrum. An accessory lamina connects podl with sprl, delimiting a narrow and deep fossa between the two laminae (Fig. $4 \mathrm{~A})$. The neural spine is short and simple, even though the distal end is eroded, and is situated above the central part of the centrum. Middle cervical vertebrae as GAL00/CL/48 and MPZ-2003/884, are more elongated than CL-2, having the first one a aEl of 4.23 for its centrum (Table 1). The cervical ribs associated with GAL00/CL/48 do not go beyond the caudal margin of the centrum, having a higher projection towards that margin than towards the cranial margin.

The only dorsal vertebra preserved is CLH-16, which corresponds to middle dorsal (fifth to seventh) (Barco, 2009). It is notably more developed lateromedially than anteroposteriorly (Fig. 4B). Although the anterior surface of the centrum is eroded, it can be described as opisthocoelous. It is shortened anterioposteriorly, with an aEl amounting to 0.67 (after Chure et al., 2010) (Table 1). The centrum presents a small pleurocoel in its left-lateral surface, with an angular dorsal margin. Internally, moreover, the centrum is practically hollow, with just one thin lamina in the middle part (Fig. 4B), so it can be defined as cam-

\begin{tabular}{|c|c|c|c|c|}
\hline & Length of centrum & $\begin{array}{c}\text { Posterior surface width } \\
\text { of centrum }\end{array}$ & Height of centrum & $\begin{array}{c}\text { E. I. } \\
\text { (Chure et al. 2010) }\end{array}$ \\
\hline Cervical CL-2 & $36.6 \mathrm{~cm}$ & $19.5 \mathrm{~cm}$ & $22 \mathrm{~cm}$ & 1.77 \\
\hline Cervical GAL00/CL/48 & $62 \mathrm{~cm}$ & $18.7 \mathrm{~cm}$ & $12 \mathrm{~cm}$ & 4.23 \\
\hline Dorsal CLH-16 & $10.8 \mathrm{~cm}$ & $20.8 \mathrm{~cm}$ & $15.8 \mathrm{~cm}$ & 0.67 \\
\hline
\end{tabular}

Table 1. Relevant measures of the cervical and dorsal vertebrae of Galvesaurus.

Tabla 1. Principales medidas de las vértebras cervicales y dorsales de Galvesaurus. 


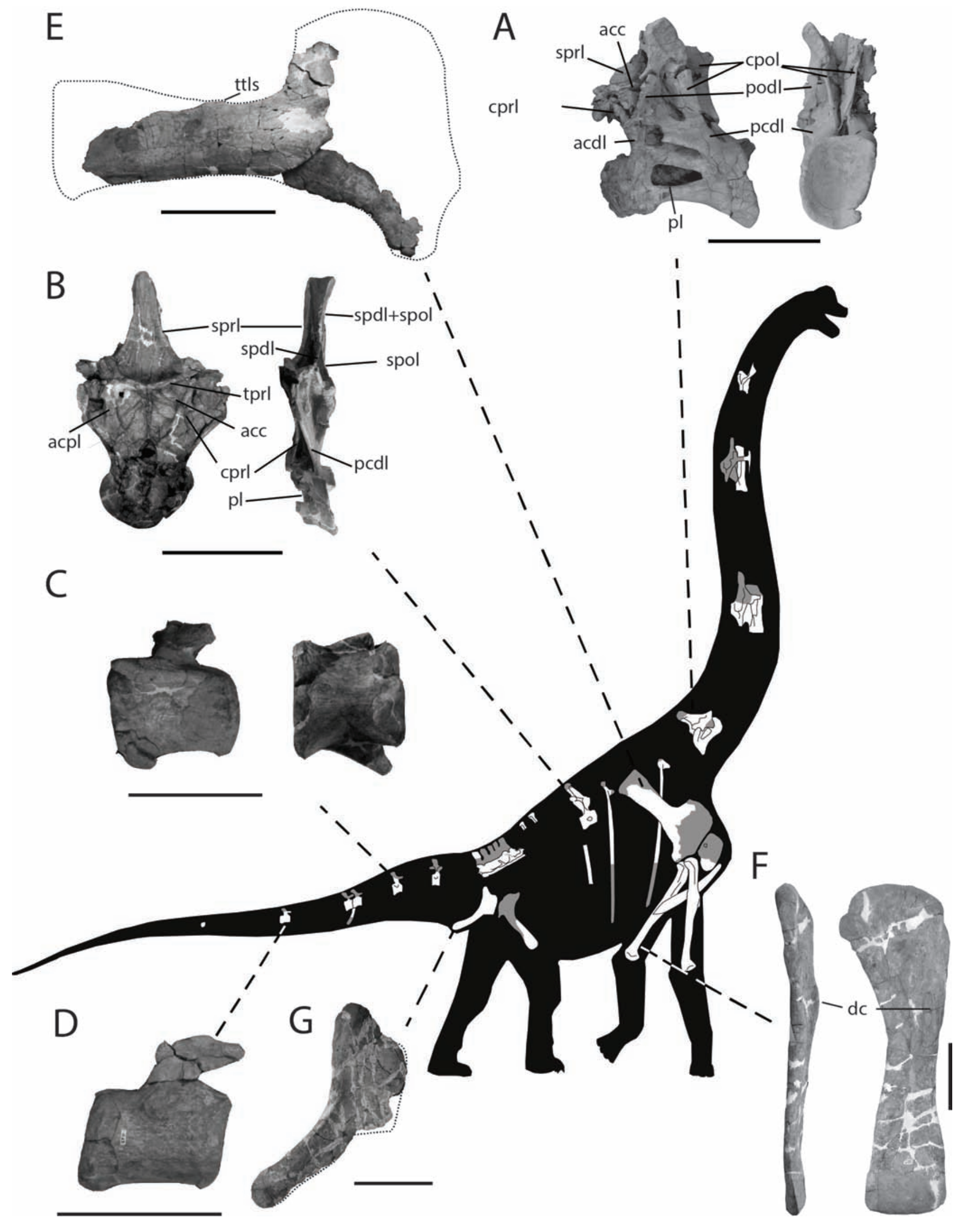


erate. The neural arch constitutes at least two-thirds of the height of the vertebra, and shows a well-marked lateromedial expansion (Fig. 4B). Like the cervical vertebrae, it has a well-developed system of laminae (Fig. 4B), comprising: anterior centrodiapophyseal (acdl) and posterior centrodiapophyseal (pcdl), anterior centroparapophyseal (acpl) intraprezygapophyseal (tprl), centroprezygapophyseal (cprl), prezygodiapophyseal (prdl), prezygoparapophyseal (prpl), centropostzygapophyseal (cpol), spinoprezygapophyseal (sprl), spinopostzygapophyseal (spol) and spinodiapophyseal (spdl). Tprl and cprl are connected with one another by an accessory lamina (Fig. 4B). The vertebra has a rhomboidal hyposphene in its posterior face, but no hypantrum. The neural spine shows two fossae delimited by the laminae spdl and sprl and lacks triangular aliform processes. However, the dorsal spines CL-JMH and GAL/00/CL/62, which correspond to posterior dorsal vertebrae, do have triangular "aliform" processes. Dorsal ribs are none of them totally complete, lacking a well-preserved proximal part, although it seems that they were not pneumatized. In cross-section, anterior ribs (GAL/00/CL/102) show a plank-like shape, meanwhile those in a posterior position have subtriangular cross-section (CLH22).

The sacrum is made up of five fused vertebrae, cylindrical in shape, slightly opisthocoelous, and lacking pleurocoels. The transverse processes of the vertebrae are connected with one another by the laminae prdl and podl, which form a practically continuous lamina. The neural spines are eroded, except the spine of S5, which preserves its distal end, albeit disarticulated from the rest of the spine. This allows a length of $28 \mathrm{~cm}$ to be estimated for the spine of S5, which is around 2.33 times more than the length of the centrum $(\sim 12 \mathrm{~cm})$. The sacral ribs are connected at their distal ends by a sacricostal yoke, which presents in its ventral margin a shallow concavity between S1 and S4. This can be interpreted as the contribution to the acetabulum of the sacrum.

The caudal centra preserved correspond to anterior and middle vertebrae (Fig. 4C and D). All of them are solid, without pneumatic cavities or pleurocoels. Their anterior and posterior articular faces are slightly concave, so they are amphicoelous. Their ventral surface is convex transversely, and they have wellmarked chevron facets (Fig. 4C), except CLH, which is one of the posterior middle vertebrae. The transverse processes are triangular in shape, developing in a middle position on the dorsal margin of the centrum. Their ventral surface is oriented slightly ventrally, whereas the dorsal surface is flat. The neural arches are simple, without laminae, located in the anterior part of the centra in the anterior vertebrae, migrating slightly towards the posterior in the middle vertebrae. No neural spines are preserved. The only haemal arch preserved lacks a crus bridging its dorsal margin, and the haemal canal would constitute approximately a quarter of the total length of the haemal arch.

Only the right scapula of Galvesaurus was found. This was poorly preserved, having lost a great part of the proximal lamina and the distal part of the scapular blade (Fig. 4). The acromion process is broad, being at least twice as wide as the blade, and its dorsal margin is concave. Due to the poor preservation of the proximal lamina, we estimated the orientation of the coracoid articulation and the glenoid (Fig. 4E). The scapular blade shows a slight dorsoventral expansion and has a 'D-shaped' transverse section. Its dorsal margin presents a small tubercle (Fig. 4E), which corresponds to the insertion of the trapezius and levator scapulae muscles (Meers, 2003). The right coracoid is poorly preserved, with only its cranioventral margin preserved, which is convex and has a subrounded contour. This suggests a rounded shape for

Figure 4. Galvesaurus herreroi skeletal reconstruction based on the holotype. A) Middle cervical vertebra in lateral and posterior view. B) Middle dorsal vertebra in anterior and lateral view. C) Anterior caudal vertebra in lateral and ventral view. D) Middle caudal vertebra in lateral view. E) Right scapula in lateral view. F) Left humerus in lateral and anterior view. G) Right ischium in lateral view. Scale bar: $30 \mathrm{~cm}$, except in C and D, which measure $15 \mathrm{~cm}$. Grey represents parts of the bones not preserved. Abbreviations: acc: accessory lamina, acdl: anterior centrodiapophyseal lamina, acpl: centroparapophyseal cpol: centropostzygapophyseal lamina, cprl: centroprezygapophyseal lamina, dc: deltopectoral crest, pcdl: posterior centrodiapophyseal lamina, podl: postzygodiapophyseal lamina, pl: pleurocoel, spdl: spinodiapophyseal lamina, spol: spinopostzygapophyseal lamina, sprl: spinoprezygapophyseal lamina, tprl: intraprezygapophyseal lamina, ttls: trapezius and levator scapulae tubercle.

Figura 4. Reconstrucción del esqueleto de Galvesaurus herreroi basada en el holotipo. A) Vértebra cervical media en vistas lateral y posterior. B) Vértebra dorsal media en vistas anterior y lateral. C) Vértebra caudal anterior en vistas lateral y ventral. D) Vértebra caudal media en vista lateral. E). Escápula derecha en vista lateral. F) Húmero izquierdo en vista lateral y anterior. G) Isquion derecho en vista lateral. La barra de escala equivale a $30 \mathrm{~cm}$, excepto en $C$ y D, que equivale a $15 \mathrm{~cm}$. El color gris representa partes de los huesos no preservadas. Abreviaturas: acc: lámina accesoria, acdl: lámina centrodiapofisial anterior, acpl: lámina centroparapofisial, cpol; lámina centropostzigapofisial, cprl: lámina centroprezigapofisial, dc: cresta deltopectoral, pcdl: lámina centrodiapofisial posterior, podl: lámina postzigapofisial, pl: pleurocelo, spdl: lámina espinodiapofisial, spol: lámina espinopostzigapofisial, sprl: lámina espinoprezigapofisial, tprl: lámina intraprezigapofisial, ttls: tubérculo del trapezius y levator scapulae. 
the coracoid (Fig. 4). There is also a sternal plate that is oval in shape, with the posterolateral margin curved. It has a maximum anteroposterior length of $64 \mathrm{~cm}$, yielding a ratio to the length of the humerus of 0.45 , which is less than the 0.75 typical of somphospondylan sauropods (Upchurch et al., 2004).

The humerus has a generally straight shape, with an elliptical midshaft cross-section (Fig. 4F). The proximomedial corner has a notch that somewhat resembles the triosseum foramen of birds' humerus and that has been observed in other sauropods, such as Tehuelchesaurus (Carballido et al., 2011). The deltopectoral crest is narrow, and is limited to the proximolateral margin of the humerus, developing only up to the middle part of the diaphysis (Fig. 4F). The articular surface of the condyles is restricted to the distal portion of the humerus. They are slender humeri, with an RI (sensu Wilson and Upchurch, 2003) of 0.25.

Regarding the pelvic girdle, the right ischium is almost complete (Fig. 4G) and $65 \mathrm{~cm}$ in length, with a proximal shaft trapezoidal in shape, with the pubic and iliac peduncles constraining the acetabular articulation, which keeps the same transverse width throughout its length. The iliac peduncle is triangular in shape, but does not show any constriction, whereas the pubic peduncle shows a partially rectangular shape, since it is somewhat eroded. The ischial blade is elongated and narrow; its distal end is not expanded (Fig. 4G). It articulates with the proximal shaft at an angle of about $100^{\circ}$, which indicates that the juncture of the ischial blades of both ischia would be almost coplanar. The right pubis is only represented by the distal end of the pubic shaft, which is not expanded and is $40 \mathrm{~cm}$ in length. On the basis of this length, we estimate a total length for the pubis of between 95$100 \mathrm{~cm}$, which would equal $145 \%$ of the length of the ischium.

\section{Phylogenetic analysis}

The phylogenetic analysis resulted in 50000 most parsimonious trees (MPTs) with a length of 1380 steps, $\mathrm{Cl}=0.360$ and $\mathrm{RI}=0.718$.

In all the trees Galvesaurus is recovered within Titanosauriformes, as a sister taxon of Lusotitan, together constituting a sister clade to the others Brachiosauridae, (Fig. 5). The characters that allow Galvesaurus to be included within Titanosauriformes are: i) a length/height ratio of the posterior articular surface of the middle cervical vertebrae higher than 4 (C142: 1); ii) scapula with the acromion process lying nearly at glenoid level (C283: 0); iii) gracile humerus (with an RI less than 0.27, sensuWilson and Upchurch,
2003) (C304: 0); and iv) pubis larger $(+120 \%)$ than ischium (C334: 1). The clade Brachiosauridae (Galvesaurus+Lusotitan+more derived Brachiosauridae) is supported by the following characters: i) Anterior and middle dorsal vertebrae with zygapophyseal articulation horizofig.ntal or slightly posteroventrally oriented (C171:0), ii) Neural spine of anterior dorsal vertebrae with a minimums width / length lower than 0.5 (C174:1), iii) Middle and posterior dorsal vertebrae neural spine with triangular aliform processes present and project far laterally (as far as caudal zygapophyses) (C196:2). In addition, according to this phylogenetic hypothesis, the characters that could be diagnostic of Galvesaurus within the latter clade would be: i) middle and posterior dorsal centrum strongly compressed in transverse section (with a ratio of the height to the width below 0.8) (C195: 2); ii) sacral vertebral centra without pleurocoels in their lateral surfaces (C219: 0); and iii) amphicoelous anterior caudal centra (C231: 0). A list of the synapomorphies that characterize the clades relevant to Galvesaurus is provided in Appendix 2.

\section{Discussion}

\section{Age of Galvesaurus}

Previous research attributed Galvesaurus to a Tithonian-Berriasian age (Barco et al., 2005; RoyoTorres et al., 2009). However, Aurell et al. (2016) date the Villar del Arzobispo Fm. as middle-upperTithonian by the presence of benthic foraminifer Anchispirocyclina lusitanica, and the absence of the middle Berriasian charophyte Globator maillardii incrassatus, which it is present in the overlaying Aguilar del Alfambra Fm. Recently Campos-Soto et al. (2017) consider Villar del Arzobispo Fm. as late Kimmeridgian in age, based on the presence of benthic foraminifer Alveosepta jaccardi-personata, although this dating was performed in the Penyagolosa sub-basin. Posteriorly, Val et al. (2018), found this foraminifer in the lower part of Villar del Arzobispo Fm. in Galve sub-basin, with its presence being limited to sequence S1.Thus, $\mathrm{S} 1$ corresponds to latest Kimmeridgian, whereas the rest of the formation would date as early Tithonian. Besides, ${ }^{87} \mathrm{Sr} /{ }^{86} \mathrm{Sr}$ isotope data confirm the dating, giving the formation a time span from 152.5 to $151 \mathrm{Ma}$.

As we have determined, the Galvesaurus site is situated in the lower part of the formation in question, just at the top of sequence S1 (Fig. 3), which means that this sauropod can be ascribed to the latest Kimmeridgian-Early Tithonian, with an estimated 


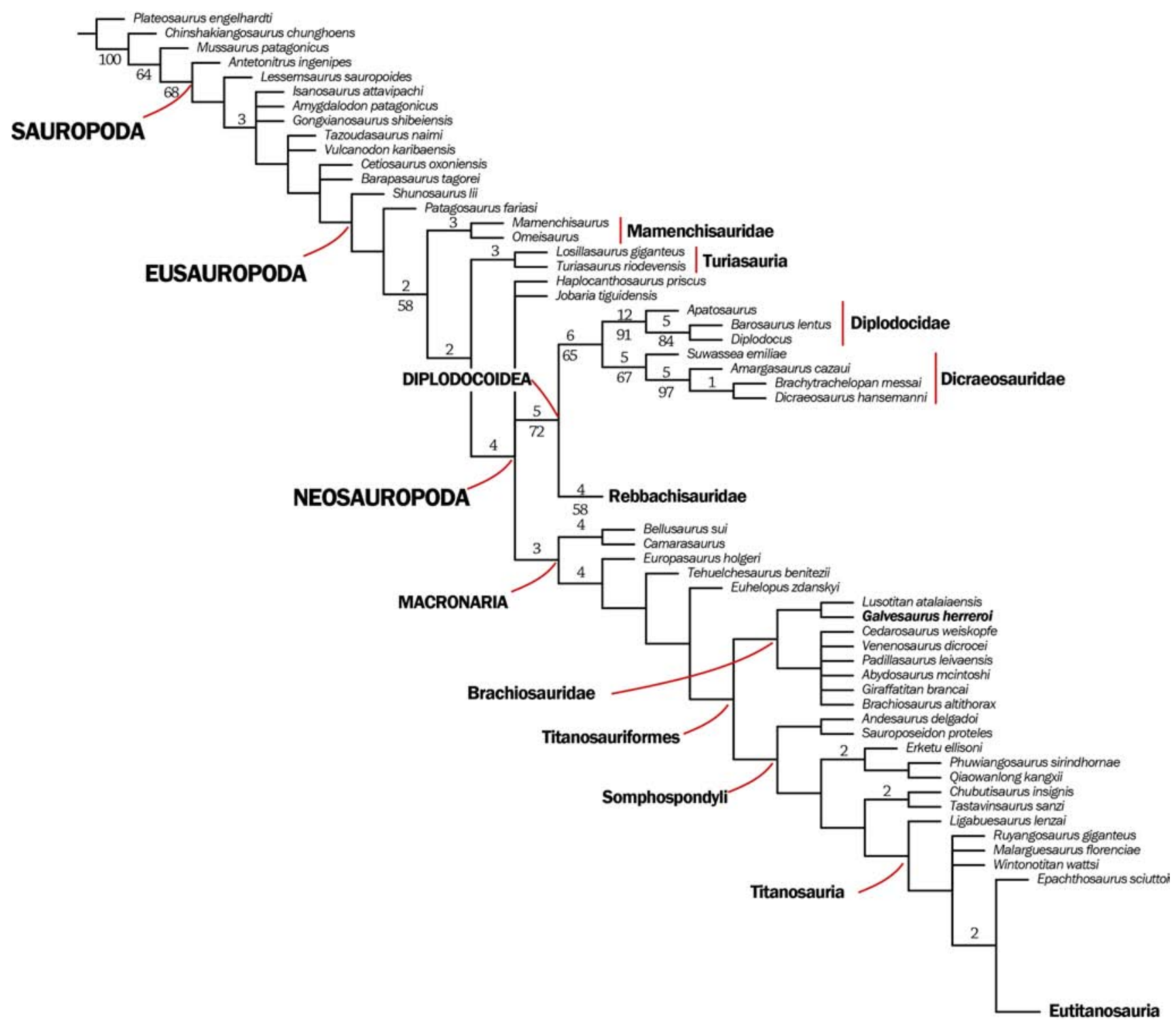

Figure 5. Strict consensus tree of the 50,000 most parsimonious trees (MPTs). Numbers over nodes represent Bremer supports over 2. Numbers below branches represent bootstrap values over 50 after a thousand replications.

Figura 5. Árbol de consenso estricto de los 50000 árboles más parsimoniosos (MPTs). Los números sobre los nodos representan soportes de Bremer con valores por encima de 2. Los números bajos las ramas representan valores de bootstrap por encima de 50 después de mil replicaciones.

occurrence span of 1.5 Ma. This delimits and narrows the temporal range of Galvesaurus to the Upper Jurassic, ruling out its presence during the Early Cretaceous.

\section{Phylogenetic position of Galvesaurus and its palaeo- biogeographic implications}

Neosauropoda is an extensive clade defined above all by cranial characters, as well as others from the carpals, astragalus and tibia (Wilson and Sereno, 1998; Upchurch et al., 2004), elements that are not preserved in Galvesaurus. However, Galvesaurus shares several characters that allow it to be included within this clade. These characters are the presence of deep pleurocoels in the presacral vertebrae; cervical pleurocoels divided by a septum; five or more sacral vertebrae; the anterior position of the neural arches in the middle caudal vertebrae; the lack of a crus bridging in the haemal arches; and ischia that present a distal end with a flattened (almost coplanar) section. 
Macronaria is defined mainly by cranial and metacarpal characters (Wilson and Sereno, 1998; Wilson, 2002; Upchurch et al., 2004). Once again, the incompleteness of the Galvesaurus skeleton hampers its inclusion in this clade. Nevertheless, Galvesaurus shares some features that allow us to include it in Macronaria, such as the presence of triangular 'aliform' processes in the neural spines of the middle and posterior dorsal vertebrae. This character is also present in some derived eusauropods, such as Omeisaurus or Turiasaurus, but in Neosauropoda it is only present in Macronaria, since it disappears in Diplodocoidea. A synapomorphy of Macronaria is also opisthocoelous centra in posterior dorsal vertebrae with, even though in some titanosauriforms this character is less developed. For Galvesaurus, this character is inferred from the shape of the first sacral centrum, which is slightly opisthocoelous.

Galvesaurus has several characteristics that support its inclusion in Titanosauriformes, such as the presence of camellae in presacral vertebrae (Wedel, 2003), having compressed caudal centra (Mocho et al., 2017), the anterior position of the neural arch in the middle caudal vertebrae (Salgado et al., 1997; D'Emic, 2012), the posterior orientation of the haemal arches, and anterior dorsal ribs with a plank-like cross-section (Wilson, 2002), although the latter is absent in basal macronarians such as Camarasaurus, which has a sub-circular section. There are also several synapomorphies of Titanosauriformes that are unknown in Galvesaurus due to the incompleteness of its remains, as well as a few that are not shared by Galvesaurus, such as the presence of proximal pneumatic cavities in the dorsal ribs (Wilson and Sereno, 1998), although the ribs preserved in Galvesaurus are scarce and there is no proximal part that is well preserved. However, we think that the evidence that supports its inclusion is stronger. This includes the results of other phylogenetic analyses, such as the one performed by D'Emic (2012) on Titanosauriformes, in which the author considers Galvesaurus to be a possible member of this clade.

It is important to note that Galvesaurus and Lusotitan atalaiensis (Lusitanian basin, Portugal, Kimmeridgian-Tithonian in age), form a clade sister to all other Brachiosauridae, with which they share some affinities. Brachiosauridae is defined by Wilson and Sereno (1998) as the most inclusive clade that includes Brachiosaurus altithorax but excludes Saltasaurus loricatus. The synapomorphies that characterize this clade according to Wilson and Sereno (1998) are: i) subrectangular muzzle (twice as long as wide, ii) elongate cervical centra (reaching a maximum of seven times as long as wide), iii) centra with deep accessory depressions, iv) elongate humerus (subequal to the femur in length); and v) humerus with prominent deltopectoral crest. Galvesaurus complies with the characters related to cervicals, has a gracile humerus (but we cannot compare its length with the femur), but it does not have such a prominent deltopectoral crest as s.s. Brachiosauridae. Furthermore, a rounded dorsolateral corner in the humerus and an abbreviated pubic peduncle in the ischium, as shown by Galvesaurus, are considered by D'Emic (2012) to be synapomorphies of Brachiosauridae.

Galvesaurus and Lusotitan appear in the analysis as sister taxa, defined by two synapomorphies: i) the middle to posterior dorsal vertebrae have pleurocoels with their dorsal margin angular (C188: 1), and ii) the posterior dorsal centra have slightly opisthocoelous articular faces (C207: 1). Mocho et al. (2017) also described as similarities the presence of dorsoventrally compressed caudal vertebrae, the anterior displacement of the neural arches in the middle caudal vertebrae, the absence of a lateral groove in the ischium, and a dorsoventrally restricted deltopectoral crest. For this reason, Mocho et al., (2017) consider arduous to differentiate Galvesaurus from Lusototitan, and they do not exclude the possibility of both taxa being synonymous. However, we have recognized several characters displayed by Galvesaurus that are not shared with Lusotitan and are relevant as phylogenetic characters (Fig. 6): such as the absence of pneumatic foramina in sacral centra (present in Lusotitan); flat ventral surface of the sacral centra (whereas Lusotitan presents a keel-like structure on its ventral surface; and slender pubic shaft, without a marked distal expansion (Lusotitan pubis has a circular expansion).

For all the reasons expounded above, we consider Galvesaurus to be a brachiosaurid sauropod, with great affinities with Lusotitan, but constituting different taxa, and with both of them being basal forms of the clade Brachiosauridae. However, we consider this hypothesis to be fallible since both sauropods are rather incomplete, relative low support of all clades in this region of the cladogram (Fig. 5) and hence there is a lack of data, especially in relation to cranial characters. Thus, this hypothesis needs to be tested with new, more complete specimens.

The Titanosauriformes was a widespread group of sauropods that probably appeared at the end of the Middle Jurassic (D'Emic, 2012) and extended across Europe, Gondwana and North America in the Late Jurassic (Fig. 7), although it seems that they did not reach Asia until the Early Cretaceous (Wilson and Upchurch, 2009; D'Emic, 2012). The inclusion of 

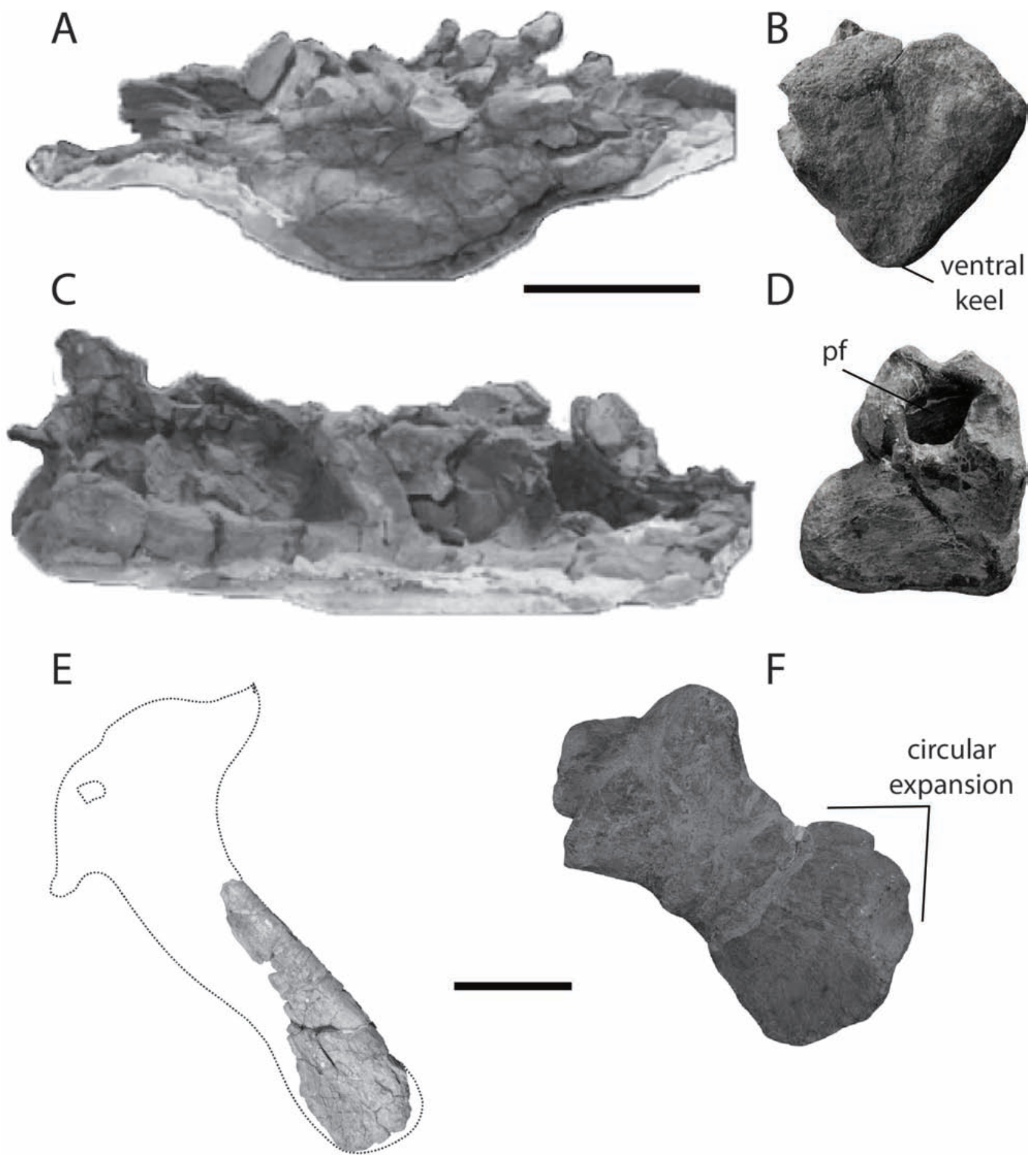

Figure 6. Comparison of the distinctive elements between Galvesaurus and Lusotitan. Sacrum of Galvesaurus (A, C) and sacral vertebra of Lusotitan (B, D) in anterior and right lateral view. Note the flat ventral surface in $A$ and the absence of pneumatic foramen in $C$, whereas $B$ shows a keel ventrally and D has pneumatic foramina. Right pubis of Galvesaurus (E) and left pubis of Lusotitan (F) in lateral view (F is a mirrored view, to resemble the right pubis). Note the slender pubic shaft of $\mathrm{E}$, whilst $\mathrm{F}$ shows a circular expansion. Bones of Lusotitan modified from Mocho et al. (2018). Scale bar equals $15 \mathrm{~cm}$ for sacra and $20 \mathrm{~cm}$ for pubes. Pf: pneumatic foramen.

Figura 6. Comparación de los elementos distintivos entre Galvesaurus y Lusotitan. Sacro de Galvesaurus $(A, C)$ y vértebra sacra de Lusotitan $(B, D)$ en vistas anterior y lateral derecha. Nótese la superficie ventral plana en $A$ y la ausencia de foramen neumático en $C$, mientras que $B$ muestra una quilla ventral y $D$ tiene un foramen neumático. Pubis derecho de Galvesaurus $(E)$ y pubis izquierdo de Lusotitan $(F)$ en vista lateral ( $F$ es una vista reflejada, para representar al pubis derecho). Obsérvese la delgada rama púbica de $E$, mientras que $F$ muestra una expansión circular. Huesos de Lusotitan modificados de Mocho et al. (2018). La barra de escala equivale a $15 \mathrm{~cm}$ para los sacros y $20 \mathrm{~cm}$ para los pubis. Pf: foramen neumático. 


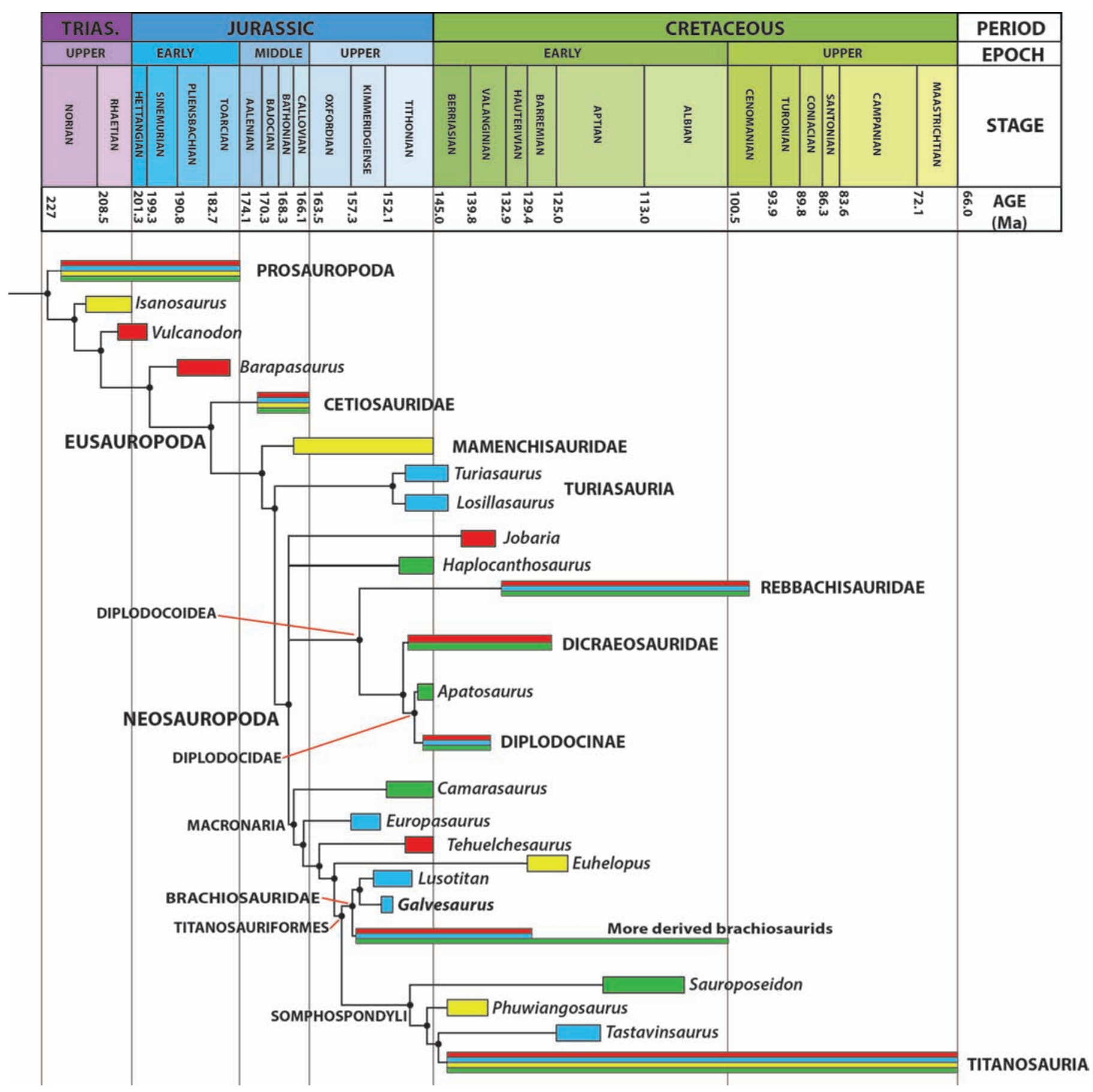

Figure 7. Time-calibrated phylogeny showing the temporal range and palaeobiogeography of the main clades of the sauropods (green = North America; blue = Europe; red = Gondwana; yellow = Asia). Ages taken from IUGS (2018).

Figura 7. Filogenia calibrada temporalmente, mostrando el intervalo temporal y la paleobiogeografía de los principales clados de saurópodos (verde = Norte América; azul = Europa; rojo = Gondwana; amarillo = Asia). Edades tomadas de IUGS (2018).

Galvesaurus in Brachiosauridae (Fig. 7) sheds new light on the abundance of this group and of titanosauriform sauropods in Iberia during the Late Jurassic. Titanosauriformes is represented during the Tithonian by the brachiosaurids Galvesaurus and
Lusotitan, and there are also several teeth (Rauhut, 2000, Royo-Torres et al., 2014) and a femur (Canudo et al., 2010) that could be assigned to Titanosauriformes. This femur could correspond to one of the two already-defined taxa, or belong to a new one, 
because it is the only Jurassic femur of a titanosauriform from Iberia. Contemporaneously, there were other groups of sauropods during the Tithonian, such as the turiasaurs Turiasaurus, Losillasaurus (RoyoTorres et al., 2009) and Zby (Mateus et al., 2012), the non-titanosauriform macronarian Lourinhasaurus (Mocho et al., 2014) and the diplodocid Dinheirosaurus (Antunes and Mateus, 2003). Within this great diversity, there are sauropods during Late Jurassic that show a certain endemism to Iberia, as turiasaurs, though they extend to North America during Early Cretaceous (Royo-Torres et al., 2017b), whereas other forms have a wider distribution, as diplodocids or brachiosaurids. The latter appear during the Middle Jurassic and flourish during the Late Jurassic, with members in North America (Brachiosaurus, Riggs, 1903), Africa (Giraffatitan, Janensch, 1914) and Europe (Europasaurus, Carballido and Sander, 2014; Lusotitan, Mocho et al., 2016; and Galvesaurus), and dubious presence in South America (Mannion et al., 2017). This almost global presence continues during Early Cretaceous, with several brachiosaurids in North America (Mannion et al., 2017) and Africa (McPhee et al., 2016). In Europe, they are only represented by the Iberian brachiosaurid Soriatitan (Royo-Torres et al., 2017a).

\section{Conclusions}

Galvesaurus herreroi was a brachiosaurid titanosauriform sauropod from the latest Kimmeridgian to early Tithonian (1.5 Ma time span) of the Maestrazgo Basin of Spain. This position is supported by the review of the paratype and the description of new, unpublished material, namely a right coracoid and a fragment of the right pubis and the recalibration of the age range of Villar del Arzobispo Fm. in the Galve sub-basin.

Galvesaurus herreroi is recovered as a sister taxon of Lusotitan atalaiensis, from the KimmeridgianTithonian of the Lusitanian basin. This clade is supported by the angular dorsal margin of the pleurocoels of the dorsal vertebrae and an opistocoelic sacrum. This phylogenetic position confirms the presence of titanosauriform sauropods in the Upper Jurassic of Spain, previously known only from fragmentary remains, and supports a closer relation between the faunas of the Maestrazgo and Lusitanian basins.

Hence, we can conclude that at least two different species of brachiosaurids inhabited the transitional environments of Iberia during the KimmeridgianTithonian, in a highly diverse sauropod ecosystem with North America and/or Gondwana influences, and endemic particularities. Nevertheless, the incompleteness of Galvesaurus leaves a degree of uncertainty in the matter. Further discoveries will help to confirm or change our hypothesis.

\section{Acknowledgements}

We would like to thank to Miguel Ángel Herrero of Museo Paleontológico de Galve for letting us access the fossils of Galvesaurus for this study. This research was part of a Master's degree final project, which was subsidized by the scholarship PEX-16-074 granted by the University Institute of Environmental Sciences (IUCA) from the University of Zaragoza. This paper forms part of the project CGL2017-85038-P and is subsidized by the Spanish Ministry of Science and Innovation, the European Regional Development Fund, and the Government of Aragón (Grupo Aragosaurus: Recursos geológicos y Paleoambientes). We are grateful to Francisco Ortega and Francesc Gascó for their valuable comments on the original version of the manuscript. Rupert Glasgow has corrected the English text. M.P-P is supported by the Spanish Ministry of Education, Culture and Sport (Grant Number FPU 16/03064). M.M-A is supported by the Fundação para a Ciência e a Tecnologia, Portugal (Grant Number SFRH/BPD/ 113130/2015).

\section{References}

Antunes, M. T., Mateus, O. 2003. Dinosaurs of Portugal. Comptes Rendus Palevol, 2 (1), 77-95.

Aurell, M., Bádenas, B., Gasca, J.M., Canudo, J.I., Liesa, C.L., Soria, A.R., Moreno-Azanza, M., Najes, L. 2016. Stratigraphy and evolution of the Galve sub-basin (Spain) in the middle Tithonian-early Barremian: Implications for the setting and age of some dinosaur fossil sites. Cretaceous Research, 65,138-162.

Aurell, M., Mas, R., Meléndez, A., Salas, R. 1994. El tránsito Jurásico-Cretácico en la Cordillera Ibérica: relación tectónica-sedimentación y evolución paleogeográfica. Cuadernos de Geología Ibérica, 18, 369-396.

Bakker, R. 1998. The Jurassic-Cretaceous transition in Wyoming and Colorado. In: Lucas, S., Kirkland; J. and Estep, J. (eds.). Lower and Middle Cretaceous Terrestrial Ecosystems: Bulletin, 1, 67-77.

Barco, J. L. 2003. Estudio y Comparación del esqueleto axial de un saurópodo (Dinosauria, Sauropodomorpha) procedente de la Formación Villar del Arzobispo (TitónicoBerriasiense) de Galve, Teruel. Bachelor thesis, Universidad de Zaragoza, $116 \mathrm{pp}$.

Barco, J.L. 2005. Estudio y comparación del esqueleto axial de un saurópodo (Dinosauria, Sauropodomorpha) procedente de la Formación Villar del Arzobispo (Titónico- 
M. Pérez-Pueyo, et al., 2019. New contributions to the phylogenetic position of the... Boletín Geológico y Minero, 130 (3): $375-392$

Berriasiense) de Galve, Teruel. Treballs del Museu de Geología de Barcelona, 13, 15-59.

Barco, J.L. 2009. Sistemática e implicaciones filogenéticas y paleobiogeográficas del saurópodo Galvesaurus herreroi (Formación Villar del Arzobispo, Galve, España). Ph. D. thesis, Universidad de Zaragoza, 405 pp.

Barco, J.L. 2010. Phylogenetic and paleobiogeographical implications of the sauropod Galvesaurus herreroi Barco, Canudo. Cuenca-Bescós y Ruiz-Omeñaca 2005. Actas de $V$ Jornadas Internacionales sobre Paleontología de Dinosaurios y su Entorno, Salas de los Infantes, Burgos, 3-6.

Barco, J. L., Canudo, J. I. 2012. On the phylogenetic position of the sauropod Galvesaurus, and other reflections. Actas de $V$ Jornadas Internacionales sobre Paleontología de Dinosaurios y su Entorno, Salas de los Infantes, Burgos, 17-29.

Barco, J. L., Canudo, J. I., Cuenca-Bescós, G. 2006. Descripción de las vértebras cervicales de Galvesaurus herreroi Barco, Canudo, Cuenca-Bescós y RuizOmeñaca, 2005 (Dinosauria, Sauropoda) del tránsito Jurásico-Cretácico en Galve (Teruel, Aragón, España). Revista Española de Paleontología, 21 (2), 189-205.

Barco, J.L., Canudo, J.I., Cuenca-Bescós, G., Ruiz-Omeñaca, J.I. 2005. Un nuevo dinosaurio saurópodo, Galvesaurus herreroi gen. nov., sp. nov., del tránsito JurásicoCretácico en Galve (Teruel, NE de España). Naturaleza Aragonesa, 15, 4-17.

Barrett, P. M., McGowan, A. J., Page, V. 2009. Dinosaur diversity and the rock record. Proceedings of the Royal Society of London, Series B: Biological Sciences, 276, 2667-2674.

Campos-Soto, S., Cobos, A., Caus, E., Benito, M. I., Fernández-Labrador, L., Suarez-Gonzalez, P., et al. 2017. Jurassic Coastal Park: A great diversity of palaeoenvironments for the dinosaurs of the Villar del Arzobispo Formation (Teruel, eastern Spain). Palaeogeography Palaeoclimatology Palaeoecology, 485, 154-177.

Canudo, J.I. 2018. The collection of type fossils of the Natural Science Museum of the University of Zaragoza (Spain). Geoheritage, 10, 385-392.

Canudo, J.I., Barco, J.L., Castanera, D., Torcida, F. 2010. New record of a sauropod in the Jurassic-Cretaceous transition of the Iberian Peninsula (Spain): palaeobiogeographical implications. Paläontologische Zeitschrift, 84 (3), 427-435.

Canudo, J.I., Carballido, J.L., Garrido, A., Salgado, L. 2018 A new rebbachisaurid sauropod from the Lower Cretaceous (Albian) of the Rayoso Formation (Neuquén, Argentina) Acta Paleontologica Polonica, 63 (4), 679-691.

Canudo, J.I., Gasca, J.M., Moreno-Azanza, M., Aurell, M. 2012. New information about the stratigraphic position and age of the sauropod Aragosaurus ischiaticus from the Early Cretaceous of the Iberian Peninsula. Geological Magazine, 149, 252-263.

Canudo, J.I., Ruiz-Omeñaca J.I., Aurell M., Barco J.L., CuencaBescós, G. 2006. A megatheropod tooth from the late Tithonian-lower Berriasian (Jurassic-Cretaceous transition) of Galve (Aragon, NE Spain). Neues Jahrbuch für Geologie und Paläontologie, Abhandlungen, 239 (1), 77-99.
Carballido, J.L, Pol, D., Otero, A., Cerda, I.A., Salgado, L., Garrido, A.C., Ramezani, J., Cúneo, N.R., Krause, J.M. 2017. A new giant titanosaur sheds light on body mass evolution among sauropod dinosaurs. Proceedings of the Royal Society B, 284, 20171219.

Carballido, J.L., Pol, D., Parra Ruge, M.L., Padilla, S., Páramo-Fonseca, M.E., Etayo-Serna, F. 2015. A new Early Cretaceous brachiosaurid (Dinosauria, Neosauropoda) from northwestern Gondwana (Villa de Leyva, Colombia). Journal of Vertebrate Paleontology. Online edition, e980505.

Carballido, J.L., Rauhut, O.W.M, Pol, D., Salgado, L. 2011. Osteology and phylogeny relationships of Tehuelchesaurus benitezii (Dinosauria, Sauropoda) from the Upper Jurassic of Patagonia. Zoological Journal of the Linnean Society, 163,605-662.

Carballido, J.L., Sander, P.M., 2014. Postcranial axial skeleton of Europasaurus holgeri (Dinosauria, Sauropoda) from Upper Jurassic of Germany: implications for sauropod ontogeny and phylogenetic relationships of basal Macronaria. Journal of Systematic Paleontology, 12, 335-387.

Casanovas, M.L., Santafé, J.V., Sanz, J.L. 2001. Losillasaurus giganteus, un nuevo saurópodo del tránsito Jurásico Cretácico de la cuenca de "Los Serranos" (Valencia, España). Paleontologia i Evolució, 32-33, 99-122.

Castanera, D., Canudo, J.I., Díaz-Martínez, I., Herrero Gascón, J., Pérez-Lorente, F. 2010. Grandes contramoldes de icnitas de saurópodos en el TithónicoBerriasiense de la Formación Villar del Arzobispo en Galve (Teruel). In: Ruiz-Omeñaca, J.I., Piñuela L. and García-Ramos, J.C. (eds.). Comunicaciones del V Congreso del Jurásico de España. Museo del Jurásico de Asturias (MUJA), Colunga, 8-11 de septiembre de 2010, 178-183.

Castanera, D., Barco, J.L., Díaz-Martínez, I., Herrero Gascón, J., Pérez-Lorente, F., Canudo, J.I. 2011. New evidence of a herd of titanosauriform sauropods from the lower Berriasian of the Iberian range (Spain). Palaeogeography, Palaeoclimatology, Palaeoecology, 310 (3-4), 227-237.

Castanera, D., Vila, B., Razzolini, N.L., Falkingham, P.L., Canudo, J.I. 2013. Manus Track Preservation Bias as a Key Factor for Assessing Trackmaker Identity and Quadrupedalism in Basal Ornithopods. PlosOne, 8(9), 10.1371/annotation/e0dba720-9eda-4457-ae5924d9d96eb8c8.

Chure, D., Britt, B.B., Whitlock, J.A., Wilson, J.A. 2010: First complete sauropod dinosaur skull from the Cretaceous of the Americas and the evolution of sauropod dentition. Naturwissenschaften, 97, 379-391.

Cobos, A., Lockley, M., Gascó, F., Royo-Torres, R., Alcalá, L. 2014. Megatheropods as apex predators in the typically Jurassic ecosystems of the Villar del Arzobispo Formation (Iberian Range, Spain). Palaeogeogeography Palaeoclimatology Palaeoecology, 399, 31-41.

Cobos, A., Royo-Torres, R., Luque, L., Alcalá, L., Mampel, L. 2010 An Iberian stegosaurs paradise: the Villar del Arzobispo Formation (Tithonian-Berriasian) in Teruel (Spain). Palaeogeogeography Palaeoclimatology Palaeoecology, 293, 223-236. 
Cuenca-Bescós, G., Canudo, J.I., Ruiz-Omeñaca, J.I. 1997. Dinosaurios del tránsito Jurásico-Cretácico en Aragón. In: Gámez Vintaned, J.A. and Liñán, E (eds.). V Jornadas Aragonesas de Paleontología "Vida y ambientes del Jurásico" Ricla, 193-221.

D'Emic M.D. 2012. The early evolution of titanosauriform sauropod dinosaurs. Zoological Journal of the Linnean Society, 166, 624-671.

Díaz-Molina, M., Yébenes, A. 1987. La sedimentación litoral y continental durante el Cretácico Inferior. Sinclinal de Galve, Teruel. Estudios Geológicos, volumen extraordinario Galve-Tremp, 3-21.

Díaz-Molina, M.; Yébenes, A; Goy, A, Sanz, J. L. 1984. Landscapes inhabited by Upper Jurassic-Lower Cretaceous archosaurs (Galve, Teruel, Spain). Third Symposium on Mesozoic Terrestrial Ecosystems, Short Papers. Tübingen, 67-72.

Goloboff, P. A. and Catalano, S. A. 2016. TNT version 1.5, including a full implementation of phylogenetic morphometrics. Cladistics, 32, 221-238.

Haq, B.U. 2014. Cretaceous eustasy revisited. Global and Planetary Change, 113, 44-58.

Harris, J. D. 2004. Confusing dinosaurs with mammals: tetrapod phylogenetics and anatomical terminology in the world of homology. The Anatomical Record Part A, 281, 1240-1246.

IUGS. 2018. International Chronostratigraphic Chart v2018/08 http://www.stratigraphy.org/ICSchart/ ChronostratChart2018-08.jpg.

Janensch, W., 1914. Übersicht über der Wirbeltierfauna der Tendaguru-Schichten nebst einer kurzen Charakterisierung der neu aufgefuhrten Arten von Sauropoden. Archiv für Biontologie, 3, 81-110

Maddison, W. P., Maddison, D. R. 2017. Mesquite: a modular system for evolutionary analysis. Version 3.31 http://mesquiteproject.org.

Mannion, P., Allain, R., Moine, O., 2017. The earliest known titanosauriform sauropod dinosaur and the evolution of Brachiosauridae. PeerJ, 5, e3217.

Mannion, P., Upchurch, P., Barnes, R.N., Mateus, O. 2013. Osteology of the Late Jurassic Portuguese sauropod dinosaur Lusotitan atalaiensis (Macronaria) and the evolutionary history of basal Titanosauriforms. Zoological Journal of the Linnean Society, 168, 98-206.

Mas, R., García, A., Salas, R., Meléndez, A., Alonso, A., Aurell, M., Bádenas, B., Benito, M.I., Carenas, J.F., GarcíaHidalgo, J., Gil, J., Segura, M. 2004. Segunda fase de rifting: Jurásico Superior-Cretácico Inferior. In: Vera, J.A. (ed.), Geología de España. SGE-IGME, Madrid, 503-510.

Mateus, O., Mannion, P.D., Upchurch, P. 2014 Zby atlanticus, a new turiasaurian sauropod (Dinosauria, Eusauropoda) from the Late Jurassic of Portugal. Journal of Vertebrate Paleontology, 34 (3), 618-634.

McPhee, B.W., Mannion, P.D., De Klerk, W.J., Choiniere, J.N. 2016. High diversity in the sauropod dinosaur fauna of the Lower Cretaceous Kirkwood Formation of South Africa: implications for the Jurassic-Cretaceous transition. Cretaceous Research, 59, 151-205.

Meers, M.M. 2003. Crocodylian forelimb musculature and its relevance to Archosauria. The Anatomical Record Part, 274, 891-916.
Mocho, P., Royo-Torres, R., Ortega, F. 2014. Phylogenetic reassessment of Lourinhasaurus alenquerensis, a basal Macronaria (Sauropoda) from the Upper Jurassic of Portugal. Zoological Journal of the Linnean Society, 170 (4), 875-916.

Mocho, P., Royo-Torres, R., Ortega, F. 2017. New data of the Portuguese brachiosaurid Lusotitan atalaiensis (Sobral Formation, Upper Jurassic). Historical Biology, 29, 789817.

Pérez-Lorente, F., Herrero-Gascón, J. 2007. El movimiento de un dinosaurio deducido de una rastrillada terópoda con estructuras de inmersión de los pies en barro y de arrastre de cola (Formación Villar del Arzobispo. Galve, Teruel, España). Revista Española de Paleontología, 22 (2), 157174.

Pérez-Lorente, F., Romero-Molina, M.M. 2001. Nuevas icnitas de dinosaurios terópodos y saurópodos en Galve y Miravete de la Sierra (Teruel, España). Geogaceta, 30, 115-118.

Pérez-Oñate, J., Cuenca-Bescós, G., Sanz, J.L. 1994. Un nuevo saurópodo del Jurásico Superior de Galve (Teruel). In: Sociedad Española de Paleontología (ed.). Comunicaciones de las $X$ Jornadas de Paleontología, 159-162.

Rauhut, O.W.M. 2000. The dinosaur fauna of the Guimarota mine. In: Martin, T., Krebs, B.,(ed.) Guimarota - $A$ Jurassic Ecosystem. Verlag Dr. Friedrich Pfeil, München, 75-82.

Riggs, E.S., 1903. Brachiosaurus altithorax, the largest kown dinosaur. American Journal of Science, 15, 299-306.

Royo-Torres, R., Cobos, A., Alcalá, L. 2006 A giant European dinosaur and a new sauropod clade. Science, 314, 19251927.

Royo-Torres, R., Cobos, A., Luque, L., Aberasturi, A., Espílez, E., Fierro, I., González, A., Mampel, L. and Alcalá, L. 2009: High european sauropod dinosaur diversity during Jurassic-Cretaceous transition in Riodeva (Teruel, Spain). Palaeontology, 5 (2), 1009- 1027.

Royo-Torres, R., Fuentes, C., Meijide, M., Meijide-Fuentes, F., Meijide-Fuentes, M. 2017a. A new Brachiosauridae sauropod dinosaur from the lower Cretaceous of Europe (Soria Province, Spain). Cretaceous Research, 80, 38-55.

Royo-Torres, R., Upchurch, P., Mannion, P.D., Mas, R., Cobos, A., Gascó, F., Alcalá, L., Sanz, J.L. 2014. The anatomy, phylogenetic relationships and stratigraphic position of the Tithonian-Berriasian Spanish sauropod dinosaur Aragosaurus ischiaticus. Zoological Journal of the Linnean Society, 171, 623-655.

Royo-Torres, R., Upchurch, P., Kirkland, J.I., DeBlieux, D., Foster, J.R., Cobos, A., Alcala, L. 2017b. Descendants of the Jurassic turiasaurs from Iberia found refuge in the Early Cretaceous of western USA. Scientific Reports 7, 14311.

Salas, R., Guimerá, J., Mas, R., Martín-Closas, C., Meléndez, A., Alonso, A. 2001. Evolution of the Mesozoic Central Iberian Rift System and its Cenozoic inversion (Iberian chain). In: Cavazza, W., Robertson, A., and Ziegler, P. (eds), Peritethyan rift/wrench basins and passive margins. Mémoires du Muséum d'Histoire Naturelle, 186, 145-185.

Salgado, L., Apesteguía, S., Heredia, S.E. 2005. A new spec- 
M. Pérez-Pueyo, et al., 2019. New contributions to the phylogenetic position of the... Boletín Geológico y Minero, 130 (3): $375-392$

imen of Neuquensaurus australis, a Late Cretaceous saltasaurine titanosaur from North Patagonia. Journal of Vertebrate Paleontology, 25 (3), 623-634

Salgado, L., Coria, A, R. A., Calvo, J. O. 1997. Evolution of titanosaurid sauropods. I: Phylogenetic analysis based on the postcranial evidence. Ameghiniana, 34 (1), 3- 32.

Sánchez-Hernández, B. 2005. Galveosaurus herreroi, a new sauropod dinosaur from Villar del Arzobispo Formation (Tithonian-Berriasian) of Spain. Zootaxa, 1034, 1-20.

Sander, P. M., Mateus, O., Laven, T., Knótschke, N. 2006. Bone histology indicates insular dwarfism in a new Late Jurassic sauropod dinosaur. Nature, 441, 739-741.

Soria A.R. 1997. La sedimentación en las cuencas marginales del surco ibérico durante el Cretácico Inferior y su control estratigráfico. Ph. D. thesis. Universidad de Zaragoza, 363 pp.

Tennant, J.P., Mannion, P.D., Upchurch, P., Sutton, M.D., Price, G.D. 2017. Biotic and environmental dynamics through the Late Jurassic-Early Cretaceous transition: evidence for protracted faunal and ecological turnover. Biological Reviews, 92, 776-814.

Upchurch, P., Barrett, P.M., Dodson, P. 2004. Sauropoda. In: Weishampel, D.B, Dodson, P., Osmolska, H., (eds.) The Dinosauria (Second Edition). Berkeley: University of California Press: 259-322.Wedel, M. J. 2003. The evolution of vertebral pneumaticity in sauropod dinosaurs. Journal of Vertebrate Paleontology, 23, 344-357.

Val, J., Aurell, M., Bádenas, B., Castanera, D., Subías, S. 2018. Cyclic carbonate-siliciclastic sedimentation in a shallow marine to coastal environment (latest Kimmeridgian-early Tithonian, Galve sub basin, Spain). Journal of Iberian Geology https://doi.org/ 10.1007/s41513-018-00098-1

Wedel, M. 2003. The evolution of vertebral pneumaticity in sauropod dinosaurs. Journal of Vertebrate Paleontology, 23 (2), 344-357.

Wilson, J.A. 1999. A nomenclature for vertebral laminae in sauropods and other saurischian dinosaurs. Journal of Vertebrate Paleontology, 19, 639-653.

Wilson, J.A. 2002. Sauropod dinosaur phylogeny: critique and cladistic analysis. Zoological Journal of the Linnean Society, 136, 215-275.

Wilson, J.A., D’Emic, M.D., Ikejiri, T., Moacdieh, E.M., Whitlock, J.A. 2011. A nomenclature for vertebral fossae in sauropods and other saurischian dinosaurs. PLOS ONE, 6 (2), e17114.

Wilson, J.A., Sereno, P.C. 1998. Early evolution and higherlevel phylogeny of sauropod dinosaurs. Society of Vertebrate Paleontology Memoir, 5, 1-68.

Wilson, J. A., Upchurch, P. 2003. A revision of Titanosaurus Lydekker (Dinosauria-Sauropoda), the first dinosaur genus with a Gondwanan distribution. Journal of Systematic Palaeontology, 1 (3), 125-160.
Wilson, J.A, Upchurch, P. 2009. Redescription and reassessment of the phylogenetic affinities of Euhelopus zdanskyi (Dinosauria: Sauropoda) from the Late Jurassic or Early Cretaceous of China. Journal of Systematic Palaeontology, 7, 199-239.

\section{Appendix 1}

Galvesaurus herreroi scoring for Carballido et al. (2017) data matrix

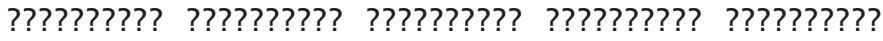

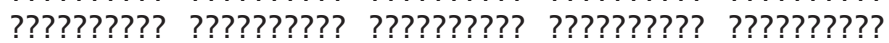

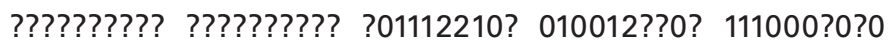
?0?-?10?11 1110-01?11 0001112?0? 011000110? 0110221001 $11110 ? 10 ? 11012110 ? 0 ? 0 ? ? 2 ? ? ? 0100000 ? 00100$ ?0000?--0 $001000 ? ? 0$ ? 000?????1? ??11????01 1000?1?0?0 $000000001 ?$

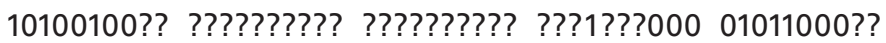
?????????? ?????????? ?????????? ?????????? ?????????? ???????00? 0?

\section{Changes on Lusotitan atalaienses codification in Carballido} et al. (2017) data matrix

136 (2 ?), 161 (? 1), 178 (? 1), 189 (? 1), 195 (? 1), 207 (? 1), 219 (? 1), 299 (0 ?), 309 (? 1), 310 (? 1), 311 (? 1), 313 (? $0 \& 1), 338$ (? 1), 339 (? 0), 340 (? 0), 342 (? 1), 348 (0 1), 367 (? 0), 368 (? 1), 370 (? 0), 371 (? 1), 373 (? 1), 374 (? 1), 412 (? 1)

\section{Appendix 2}

Unambiguous synapomorphies for the main sauropod clades

Node 104, Neosauropoda: $171\left(\begin{array}{ll}0 & 1\end{array}\right), 246\left(\begin{array}{ll}0 & 1\end{array}\right), 363\left(\begin{array}{ll}0 & 1\end{array}\right)$, $376\left(\begin{array}{ll}0 & 1\end{array}\right)$.

Node 106, Macronaria: $93\left(0\right.$ 1), $96\left(\begin{array}{ll}0 & 1\end{array}\right), 157\left(\begin{array}{ll}1 & 0\end{array}\right), 174(1$ 0), $207\left(\begin{array}{ll}0 & 2\end{array}\right), 320\left(\begin{array}{ll}0 & 1\end{array}\right), 321\left(\begin{array}{ll}0 & 1\end{array}\right), 337\left(\begin{array}{ll}0 & 1\end{array}\right), 342\left(\begin{array}{ll}0 & 1\end{array}\right)$, occasionally $165\left(\begin{array}{ll}0 & 1\end{array}\right), 283\left(\begin{array}{ll}0 & 1\end{array}\right)$.

Node 107, Galvesaurus+Lusotitan: $188\left(\begin{array}{ll}0 & 1\end{array}\right), 207(2$ 1). Node 108, Brachiosauridae (Galvesaurus+Lusotitan+other Brachiosauridae): 171 (1 0), $174\left(\begin{array}{ll}0 & 1\end{array}\right), 196(1 \quad 2)$.

Node 109, Titanosauriformes: $18(0$ 1), 100 (1 2), 106 (1 0), $109\left(0\right.$ 1), $142\left(0 \begin{array}{ll}0 & 1\end{array}\right), 195\left(\begin{array}{lll}0 & 1\end{array}\right) 283\left(\begin{array}{ll}1 & 0\end{array}\right), 304\left(\begin{array}{ll}1 & 0\end{array}\right), 334$ $\left(0\right.$ 1), $355\left(\begin{array}{ll}1 & 2\end{array}\right)$, occasionally $353\left(\begin{array}{ll}1 & 2\end{array}\right)$.

Node 116, Somphospondyli: 178 (0 1), Char. 185 (0 1). Node 117, more derived Brachiosauridae: 169 (1 0), 173 (0 2), $181(0$ 1), 203 (1 0$), 205\left(\begin{array}{ll}0 & 1\end{array}\right), 228\left(\begin{array}{ll}0 & 1\end{array}\right)$. Node 121, Titanosauria: $163\left(\begin{array}{ll}1 & 0\end{array}\right), 166\left(\begin{array}{ll}0 & 1\end{array}\right)$.

Recibido: septiembre 2018

Revisado: abril 2019

Aceptado: abril 2019

Publicado: septiembre 2019 